Central Washington University

ScholarWorks@CWU

\title{
Contributions of wood smoke and vehicle emissions to ambient concentrations of volatile organic compounds and particulate matter during the Yakima wintertime nitrate study
}

\author{
Graham VanderSchelden \\ Washington State University \\ Benjamin de Foy \\ Saint Louis University \\ Courtney Herring \\ Washington State University \\ Susan D. Kaspari \\ Central Washington University \\ Tim VanReken \\ Washington State University
}

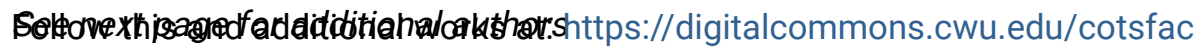

Part of the Atmospheric Sciences Commons, Climate Commons, and the Geophysics and Seismology Commons

\section{Recommended Citation}

VanderSchelden, G., B. de Foy, C. Herring, S. Kaspari, T. VanReken, and B. Jobson (2017), Contributions of wood smoke and vehicle emissions to ambient concentrations of volatile organic compounds and particulate matter during the Yakima wintertime nitrate study, J. Geophys. Res. Atmos., 122, 1871-1883, doi:10.1002/2016JD025332.

This Article is brought to you for free and open access by the College of the Sciences at ScholarWorks@CWU. It has been accepted for inclusion in All Faculty Scholarship for the College of the Sciences by an authorized administrator of ScholarWorks@CWU. For more information, please contact scholarworks@cwu.edu. 


\section{Authors}

Graham VanderSchelden, Benjamin de Foy, Courtney Herring, Susan D. Kaspari, Tim VanReken, and Bertram Jobson 


\section{Journal of Geophysical Research: Atmospheres}

\section{RESEARCH ARTICLE}

10.1002/2016JD025332

Key Points:

- RWC was found to be a substantial source of gas phase air toxics in wintertime

- The MLR model results suggest that MOVES was overpredicting mobile source emissions of $\mathrm{CO}$ relative to $\mathrm{NO}_{x}$ by a factor of 1.33

- MOVES was overpredicting mobile source emissions of black carbon relative to $\mathrm{NO}_{x}$ by a factor of 3

Supporting Information:

- Supporting Information S1

Correspondence to:

B. Jobson,

tjobson@wsu.edu

Citation:

VanderSchelden, G., B. de Foy,

C. Herring, S. Kaspari, T. VanReken, and

B. Jobson (2017), Contributions of wood

smoke and vehicle emissions to

ambient concentrations of volatile

organic compounds and particulate

matter during the Yakima wintertime nitrate study, J. Geophys. Res. Atmos.

122, 1871-1883, doi:10.1002/

2016JD025332.

Received 6 MAY 2016

Accepted 22 DEC 2016

Accepted article online 10 JAN 2017

Published online 2 FEB 2017

o2017. American Geophysical Union. All Rights Reserved.

\section{Contributions of wood smoke and vehicle emissions to ambient concentrations of volatile organic compounds and particulate matter during the Yakima wintertime nitrate study}

\author{
Graham VanderSchelden ${ }^{1}\left(\mathbb{D}\right.$, Benjamin de Foy ${ }^{2}$ (D) Courtney Herring ${ }^{1}$, Susan Kaspari ${ }^{3}$ (D), \\ Tim VanReken ${ }^{1}$ (D), and Bertram Jobson ${ }^{1}$ (D)
}

${ }^{1}$ Laboratory for Atmospheric Research, Department of Civil and Environmental Engineering, Washington State University, Pullman, Washington, USA, ${ }^{2}$ Department of Earth and Atmospheric Sciences, Saint Louis University, St. Louis, Missouri, USA, ${ }^{3}$ Department of Geological Sciences, Central Washington University, Ellensburg, Washington, USA

\section{Introduction}

A comprehensive air quality study was performed during January 2013 to investigate sources of air pollution in Yakima, WA. Particulate matter $\left(\mathrm{PM}_{2.5}\right)$ concentrations in the region have approached the Environmental Protection Agency (EPA) $24 \mathrm{~h}$ standard in recent years, with the highest $\mathrm{PM}_{2.5}$ days occurring during wintertime. Residential wood combustion and vehicles are the major wintertime sources of particulate matter (PM) and toxic air pollutants in Yakima according to the 2011 National Emissions Inventory (NEI). While the Motor Vehicle Emission Simulator (MOVES) 2010b model is an established method for estimating emissions from mobile sources [Environmental Protection Agency, 2010], the emission inventory for residential wood combustion is not as well constrained. This uncertainty stems from the difficulty in quantifying wood combustion activity levels that are often determined using community surveys, which are expensive and quickly outdated due to changes in populations and device usage [Tian et al., 2004]. Residential wood combustion has been found to be a major source of ambient $\mathrm{PM}_{2.5}$ in wintertime in a variety of different air sheds [Maykut et al., 2003; Ward et al., 2006; Alfarra et al., 2007; Lanz et al., 2008; Ward and Lange, 2010], but its role as a source of air toxics has received much less attention. Quantifying the role of residential wood combustion as a multipollutant source relative to other sources of air pollution is important for health impact assessments of wood combustion. Chemical mass balance modeling provides a straightforward means to assess source contributions in air sheds dominated by only a few sources, allowing air quality managers to clearly identify solutions for management of wintertime air quality and articulate these strategies to the community.

The wintertime 2011 NEI provided the most recent emission estimates for comparison to findings of this study. Emission estimates were compiled by the Washington State Department of Ecology (WSDOE), and a description of the emission estimation process is available in WSDOE's 2011 Emissions Inventory 
Documentation [WSDOE, 2013]. Mobile source emissions were determined by WSDOE using the MOVES model version $2010 \mathrm{~b}$, utilizing a hybrid of specific local data from state and local agencies mixed with EPA default inputs. The procedure for assembling the emission inventory for residential wood smoke was more complicated, leaving more room for uncertainty. The residential wood smoke inventory was developed using activity levels from a 2007 survey on wood-burning device usage in western Washington from the National Research Center (NRC) and using emission factors from the EPA's 2011 residential wood combustion tool. Emission factors are reported in the 2011 Emissions Inventory Documentation [WSDOE, 2013]. Yakima county wood-burning device usage rates were compiled from averaged NRC survey results from Pierce, Kitsap, and Snohomish Counties. Device usage rates, fuel usage rates, percentage of devices that were EPA certified, and percentage of EPA-certified devices that were catalytic were all determined using survey data, industry data, and assumptions on fuel dry weight for common wood quantity units (such as chords, bundles, and pickup loads). Emission factors from the EPA's residential wood combustion tool were reported across all device types for all criteria pollutants but were only provided for a few air toxics and not comprehensively across all device types. Residential wood combustion emissions were allocated seasonally: $68 \%, 20 \%, 13 \%$, and $0 \%$ for winter, fall, spring, and summer, respectively. These emission rates are incorporated into the emission inventory used in hourly chemical forecasts for the Pacific Northwest region using the Air Indicator Report for Public Awareness and Community Tracking (AIRPACT) version 4 model system [Vaughan et al., 2004].

Lack of available survey data or observations of residential wood-burning activity are the primary reason for uncertainties in the emission inventory. In this case, the counties for which survey data were used by WSDOE are located in western Washington, across the Cascade Mountains. Survey data from Pierce, Kitsap, and Snohomish Counties were used to develop the residential wood combustion emission estimates for the 2011 National Emissions Inventory which is referenced in this paper. This is a potential source of uncertainty in the inventory since the climate is different in Yakima County than in any of the three counties from where survey data were used. The mean January temperature from 1981 to 2013 was $-0.4^{\circ} \mathrm{C}$ in Yakima County but $4.8^{\circ} \mathrm{C}, 5.9^{\circ} \mathrm{C}$, and $4.9^{\circ} \mathrm{C}$ in Kitsap, Pierce, and Snohomish Counties, respectively. Colder temperatures in Yakima suggest that more wood is likely to be burned for heating per household than in the warmer counties. Additionally, the income demographic is different in Yakima County than the other three. The median household income from the American Community Survey 2013 was \$43,506 for Yakima County, while it was $\$ 62,413, \$ 59,204$, and $\$ 68,381$ for Kitsap, Pierce, and Snohomish Counties, respectively. Differences in income levels could indicate differences in home heating fuel use. Interestingly, American Community Survey 20112013 estimates that 4.9\% of household units in Yakima County use wood for home heating, while the WSDOE estimate for the NEI was that $31.6 \%$ of households use wood-burning devices. This discrepancy is likely because WSDOE was estimating the percentage of wood-burning devices used, while the American Community Survey was tabulating percentage of households that utilize wood as their primary source of heat.

In this paper, a two-source chemical mass balance model using multiple linear regression (MLR) analysis [de Foy and Schauer, 2015] was applied to determine the contributions of residential wood combustion and mobile sources to ambient concentrations of carbon monoxide (CO), a few organic air toxics, organic PM, and black carbon. The results from the chemical mass balance models were compared to MOVES model output for on-road vehicles and wood smoke emission ratios from the literature. The goal of this study was to determine the relative contribution of residential wood combustion and mobile sources on wintertime air pollutants for comparison to the emission inventory.

\section{Experiment}

\subsection{Site Description}

The Yakima Wintertime Nitrate Study took place from 5 to 27 January 2013 in Yakima Washington to assess the air pollution sources and wintertime meteorology that cause elevated wintertime $\mathrm{PM}_{2.5}$ [VanReken et al., 2014]. Yakima is a relatively small city with an estimated population of 93,357 in 2013, located in the Upper Yakima Valley. The Upper Yakima Valley is bordered by the Cascade Mountains to the west and hills to the north and south that rise about to a $200 \mathrm{~m}$ height above the valley floor. These hills come together in the east to form an enclosed basin that restricts airflow, especially when inversion heights are low. Due to its location in the rain shadow of the Cascades, Yakima's climate is classified as semiarid. January weather is characterized 
by average high and low temperatures of $3.8^{\circ} \mathrm{C}$ and $-4.6^{\circ} \mathrm{C}$ and $28.7 \mathrm{~mm}$ of precipitation on average (19812010 mean) [VanReken et al., 2014]. During January 2013, temperatures were close to their historical averages with average highs and lows of $3.4^{\circ} \mathrm{C}$ and $-4.4^{\circ} \mathrm{C}$, respectively. However, 2013 saw a much drier January than usual, with only $2.5 \mathrm{~mm}$ of recorded precipitation [VanReken et al., 2014].

Instrumentation used in this study was housed in the Laboratory for Atmospheric Research Mobile Atmospheric Chemistry Lab (MACL). The MACL is a $6 \mathrm{~m}$ long climate-controlled trailer with a $10 \mathrm{~m}$ tall crank-up tower designed to accommodate instruments and inlets. The MACL was deployed on the softball field at the Campus of Yakima Valley Community College $\left(46.58854^{\circ} \mathrm{N}, 120.5283^{\circ} \mathrm{W}\right.$; elevation $\left.327 \mathrm{~m}\right)$. This site was about $40 \mathrm{~m}$ south of Arlington Road, which was used primarily for student parking. The major arterials are South 16th Ave and West Nob Hill Blvd $150 \mathrm{~m}$ west and $400 \mathrm{~m}$ south of the site, respectively. The site was located in a mixed residential and commercial neighborhood about $2 \mathrm{~km}$ southwest of the urban center. There were significant wood smoke emissions visible from chimneys of nearby residences, suggesting that many houses used wood fuel for home heating.

\subsection{Instrumentation}

Gas phase sampling for carbon dioxide $\left(\mathrm{CO}_{2}\right)$, ozone $\left(\mathrm{O}_{3}\right), \mathrm{CO}$, and volatile organic compound (VOC) instruments was performed through a common 1/2" outer diameter (OD) perfluoroalkoxy sample line with a funnel on the inlet end to protect against snow and rain. The inlet for the common sample line was positioned on top of the $10 \mathrm{~m}$ tower, and air was pulled through the line at approximately 30 liters per minute; instruments in the trailer were subsampled from this flow. A proton transfer reaction-mass spectrometer (PTR-MS; lonicon Analytik, Austria) was used to measure VOCs and is described in detail in the literature [Lindinger et al., 1998; de Gouw and Warneke, 2007]. The PTR-MS was operated in concert with a sample dehumidifier, described in detail by Jobson and McCoskey [2010]. Dehumidifying sample air limits the amount of clustering of ambient water vapor with $\mathrm{H}_{3} \mathrm{O}^{+}$ions, allowing the PTR-MS to be operated at $80 \mathrm{Td}\left(U_{\text {drift }}=328 \mathrm{~V}, P_{\text {drift }}=2.08 \mathrm{mbar}\right.$, and $T_{\text {drift }}=65^{\circ} \mathrm{C}$ ) to reduce fragmentation and to enhance sensitivity. The PTR-MS response was calibrated using an external compressed air standard (Scott Marrin) containing 13 components with a stated accuracy of $\pm 5 \%$. The instrument response to formaldehyde was determined using a permeation device (Kin Tek). CO was measured using a vacuum UV fluorescence instrument (Aerolaser, Germany), and response was calibrated to a CO standard (Scott Marrin, $1 \%$ accuracy). Nitrogen oxide $\left(\mathrm{NO}_{x}\right)$ measurements were made using a two-channel $\mathrm{NO}_{\mathrm{x}} / \mathrm{NO}_{\mathrm{y}}$ chemiluminescence analyzer (Air Quality Design, USA). The $\mathrm{NO}_{\mathrm{x}} / \mathrm{NO}_{\mathrm{y}}$ inlet system was mounted on the tower about $4 \mathrm{~m}$ below the other gas phase inlet in a National Electrical Manufacturers Association enclosure. The inlet system consists of flow controllers, a molybdenum catalyst for converting $\mathrm{NO}_{\mathrm{y}}$ to $\mathrm{NO}$, and a photolysis cell for conversion of $\mathrm{NO}_{2}$ to $\mathrm{NO}$. Sample air was drawn from the inlet box into the MACL through 0.25 " OD tubing to be analyzed by the main instrument. One channel of the instrument was dedicated to making continuous $\mathrm{NO}_{y}$ measurements. The other channel was dedicated to making $\mathrm{NO}_{x}$ measurements, with sample air passing through the $\mathrm{NO}_{2}$ photolysis cell and having the lamp toggled on and off every $30 \mathrm{~s}$. NO mixing ratios were measured when the lamp was off, while $\mathrm{NO}_{2}$ mixing ratios were calculated from the difference in signal of lamp-on periods and lamp-off periods.

The aerosol inlet was positioned on the tower about $3 \mathrm{~m}$ below the main gas phase inlet. The particle inlet system consisted of a $0.5^{\prime \prime}$ copper tube wrapped in heating tape that was thermostated to $10^{\circ} \mathrm{C}$ to prevent ice buildup in the inlet system. The flow rate through the aerosol inlet was 4 liters per minute. The aerosol sample flow was passed through a Nafion dehumidifier to dry particles prior to sampling to allow easier intercomparison of the different aerosol measurements. Black carbon mass in individual particles between $\sim 80$ and $650 \mathrm{~nm}$ was measured using a Single-Particle Soot Photometer (SP2) [Schwarz et al., 2006], following the SP2 alignment adjustment and calibration recommendations made by Laborde et al. [2012]. The composition of submicron nonrefractory particulate matter was measured by a high-resolution time-of-flight aerosol mass spectrometer (AMS; Aerodyne, USA). A detailed description of the AMS is available in the literature by DeCarlo et al. [2006]. The AMS is capable of separating and detecting semivolatile components of aerosols including sulfate, nitrate, ammonium, chloride, and total organic matter. The AMS cannot detect nonvolatile PM, black carbon, and crustal elements, for example. The AMS was calibrated in the field including a lens alignment, flow calibration, $\mathrm{m} / \mathrm{z}$ calibration, and particle size calibration at the beginning of the study. Ionization efficiency calibrations were performed at the beginning, middle, and end of the study, 
and $\mathrm{m} / \mathrm{z}$ calibration and tuning was performed daily. AMS detection limits were determined from five filter collections and are shown in Table $\mathrm{S} 1$ in the supporting information.

\subsection{Chemical Mass Balance Model}

A chemical mass balance model for source apportionment uses a linear combination of tracer compounds to reconstruct the ambient concentration of a pollutant. The chemical mass balance model concept is described in detail in the literature [Friedlander, 1973; Watson, 1984; Watson et al., 1990; Fujita et al., 1994]. The general form of the chemical mass balance equation is shown in equation (1):

$$
C=\sum E_{i} \cdot T_{i}
$$

where $C$ is the measured pollutant concentration, which is assumed to be a result of contribution from some fixed number of sources $n$, whose relative contributions to the measured amount can change with time. The contributions of each source $i$ can be accounted for by measuring a unique tracer of that source $T_{i}$. The contribution of the source to the measured pollutant $C$ is accounted for by the emission factor $E_{i}$, which is the amount of pollutant $C$ emitted per unit of tracer compound $T$.

This approach can work if the pollutants are conserved and not lost by atmospheric processing during the time scale from emission to measurement. In Yakima, the 2011 wintertime county emission inventory suggests that there are only two significant sources of $\mathrm{CO}, \mathrm{NO}_{\mathrm{x}}, \mathrm{VOCs}$, and semivolatile $\mathrm{PM}$ : residential wood burning and mobile sources. The winter season 2011 county-level emission inventory for $\mathrm{CO}$ and $\mathrm{NO}_{\mathrm{x}}$ shows that mobile sources are responsible for $90 \%$ and $95 \%$ of anthropogenic emissions, respectively. Wood smoke is responsible for $10 \%$ of $\mathrm{CO}$ and $2 \%$ of $\mathrm{NO}_{\mathrm{x}}$. For $\mathrm{PM}_{2.5}$, the winter emission profile is dominated by wood smoke and mobile sources if road dust, construction dust, agricultural tilling, and outdoor burning are ignored. Ignoring these components for the chemical mass balance model approach is reasonable because the AMS instrument is unable to measure nonvolatile crustal elements, meaning that road dust, construction dust, and agricultural tilling will not show up in AMS measurements of PM. Additionally, burn bans were in effect during the study that prohibited outdoor burning, principally of agricultural waste. VOC emissions are dominated by wood combustion and mobile sources in the emission inventory. However, smaller influences from solvents/gasoline fuel transport/storage/filling stations could complicate the chemical mass balance model approach for some organics.

Given the predominance of residential wood combustion and mobile sources in the emission inventory we used a two-component chemical mass balance model using acetonitrile $\left(\mathrm{CH}_{3} \mathrm{CN}\right)$ and $\mathrm{NO}_{\mathrm{x}}$ as the source tracers. Acetonitrile has been shown to be a good general tracer compound of biomass burning, as acetonitrile mixing ratios are enhanced in biomass-burning plumes but do not show a significant increase in urban or power plant plumes [de Gouw et al., 2003]. Acetonitrile has been used as a biomass-burning marker in many other studies to track forest biomass-burning plumes [de Gouw et al., 2003; Karl et al., 2007; Yokelson et al., 2009; Lack et al., 2013] and agricultural burning [Holzinger et al., 2005; Yokelson et al., 2009; Yuan et al., 2010]. Acetonitrile does have some emission from motor vehicle exhaust, as suggested by Holzinger et al. [2001]. To assess this potential influence, we used data from own direct measurements of motor vehicle exhaust emissions [Erickson et al., 2014]. These data show $\sim 0.4 \%$ emission ratio of acetonitrile to toluene for gasoline engine exhaust. Given the measured abundance of toluene, and assuming that all toluene was from vehicles, the contribution from traffic sources is estimated to be less than $5 \%$ of the measured acetonitrile abundance in Yakima. For $\mathrm{NO}_{\mathrm{x}}$, given the 2014 emission inventory distribution, mobile sources are responsible for $95 \%$ of the $\mathrm{NO}_{\mathrm{x}}$ emissions and wood smoke is responsible for around $2 \%$. Although there is some contribution from each source to each tracer, the contributions are estimated to be small, and thus, the tracers are a relatively unique identifier of their respective major source.

During the model period $\mathrm{NO}_{x}$ made up $93 \%$ of $\mathrm{NO}_{y}$ on average, suggesting that $\mathrm{NO}_{x}$ was well conserved. In wintertime, photochemical loss of $\mathrm{VOCs}$ and $\mathrm{NO}_{2}$ from the air shed is thought to be insignificant. Photochemical modeling of wintertime urban air chemistry in this region using the AIRPACT forecast model system [Chen et al., 2008] indicates average daytime $\mathrm{HO}$ concentrations of $2 \times 10^{5}$ molecules $/ \mathrm{cm}^{3}$ during clear-sky conditions, resulting in an $\mathrm{NO}_{2}$ lifetime of $\sim 60 \mathrm{~h}$, much longer than travel times across the town assuming low $1 \mathrm{~m} \mathrm{~s}^{-1}$ wind speeds $(\sim 3 \mathrm{~h})$. The photochemical lifetimes of the tracers and other pollutants are long compared to transport times in the air shed and are thus considered reasonably well conserved 
for chemical mass balance modeling. With the two sources defined, the chemical mass balance model applied to the data is shown in equation (2):

$$
\left[C_{\text {poll }}\right]=C_{o}+E_{\mathrm{ws}} \cdot\left[\mathrm{CH}_{3} \mathrm{CN}\right]+E_{\mathrm{mob}} \cdot\left[\mathrm{NO}_{\mathrm{x}}\right]
$$

where $\left[C_{\text {poll }}\right]$ is the pollutant mixing ratio, $E_{\mathrm{ws}}$ is the emission ratio for wood smoke relative to acetonitrile, $E_{\text {mob }}$ is the emission ratio for mobile source emissions relative to $\mathrm{NO}_{\mathrm{x}}$, and $C_{0}$ is the amount unattributed to either source. Because $\mathrm{CO}$ and acetonitrile are long-lived in the atmosphere, regional backgrounds were removed from the time series for these species so that time series used in the chemical mass balance model would be representative of the enhancement caused by local emissions. Regional backgrounds for $\mathrm{CO}$ and acetonitrile are defined below in section 3.1.

The chemical mass balance model concept was executed using a multiple linear regression (MLR) model developed by de Foy and Schauer [2015]. The emission ratios were obtained by applying a least squares inversion directly to the concentration time series. Because the least squares method is sensitive to outliers, we use an iteratively reweighted least squares (IRLS) procedure. Residuals of the fit were calculated after each iteration of the multiple linear regression process and points were removed that had residuals higher than 2 standard deviations of the residuals. After two iterations the method converged on a stable set of outliers and the emission ratios were calculated from the remaining data points. The distributions of the data for many compounds were lognormal. An initial IRLS analysis was done on the log-transformed data. This procedure produced residuals that were normally distributed and allowed for a clear identification of outliers based on the $2 \sigma$ deviation criteria. The results of the log-transformed method in terms of goodness of fit and outlier identification were similar (see Table S2) and provided a level of quality assurance in the IRLS procedure. The regression coefficients determined from the log-transformed data are more difficult to interpret, whereas the untransformed data yield regression coefficients that are molar ratios and thus can be easily compared to emission inventories.

Uncertainty in the emission factors was estimated using the block-bootstrap procedure [de Foy and Schauer, 2015]. One-hundred realizations of the regression were simulated by randomly selecting individual hours to be included in the analysis. For each hour selected by the bootstrap, all the data points in that hour were included in the regression. When performing bootstrapping, the selection was done with replacement so that the total number of hours included in the analysis was unchanged but some hours were included more than once, whereas other hours may be left out. The uncertainty was reported as the standard deviation of the emission factors calculated by the 100 MLR realizations.

\section{Results}

\subsection{Regional Backgrounds}

The backgrounds for $\mathrm{CO}$ and acetonitrile were determined by averaging mixing ratios during periods of high winds on 7 January (WNW flow at $7.5 \mathrm{~m} / \mathrm{s}$ ) and 9 January (SW flow at $5.4 \mathrm{~m} / \mathrm{s}$ ). These periods are depicted in the pollutant time series shown in Figures 1 and 2. The high-wind speeds ensured a well-ventilated air shed, whose composition reflects the regional background. The lowest levels of $\mathrm{CO}$ and acetonitrile during the campaign were observed during this windy period: for 7 January, $\mathrm{CO}=133 \pm 5$ ppbv and $\mathrm{CH}_{3} \mathrm{CN}=44 \pm 17$ parts per trillion by volume (pptv) and for 9 January, $\mathrm{CO}=118 \pm 3$ and $\mathrm{CH}_{3} \mathrm{CN}=52 \pm 13$ pptv. The differences in the $\mathrm{CO}$ background mixing ratios likely reflect differences in air mass origin given differences in synopticscale airflow. The larger uncertainty for acetonitrile reflects measurement precision at these low mixing ratios. The low level of acetonitrile compares well with acetonitrile measurements ( $56 \pm 20 \mathrm{pptv}$ ) reported from a location near Tucson, AZ, in September [Snider and Dawson, 1984]. This acetonitrile background was significantly lower than the background that has been observed in many other studies of about 100-400 pptv [Karl et al., 2002; Jost et al., 2003; Yuan et al., 2010]. Differences between studies may reflect seasonal and regional variations. For the analysis period, where wind flow typically had a more southerly component, we used the 118 ppbv $\mathrm{CO}$ background value and a 40 pptv background value for acetonitrile, which resulted in positive but near-zero values of $\mathrm{CH}_{3} \mathrm{CN}$ in the afternoons.

\subsection{Data Selection for the Chemical Mass Balance Model}

The chemical mass balance model was run for a clear-sky period during the beginning of the study, where there was significant variability of pollutants and tracer species due to meteorological variation (mixing 


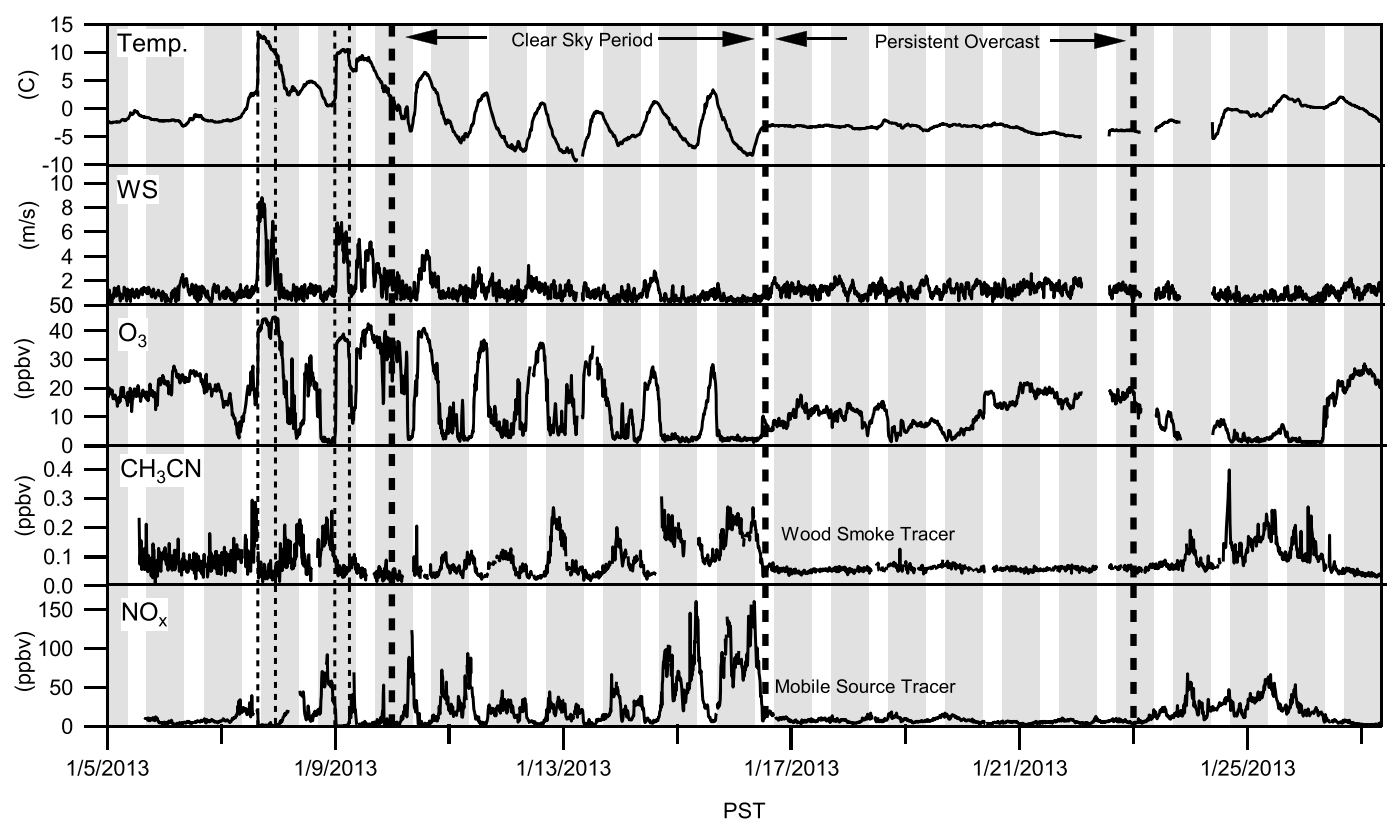

Figure 1. Time series of temperature, wind speed, ozone, acetonitrile (wood smoke tracer), and $\mathrm{NO}_{\mathrm{x}}$ (mobile source tracer). The areas denoted by dashed lines on 07 and 09 January indicate the high-wind period, during which regional backgrounds were determined for $\mathrm{CO}$ and $\mathrm{CH}_{3} \mathrm{CN}$. Shaded areas indicate nighttime and unshaded areas indicate daytime.

height variation). This was a 5 day period from 11 January (00:00) to 16 January (00:00). This period was characterized by sunny skies, significant diel temperature variation, and low to moderate winds. Figure 1 displays the time series of temperature, wind speed, ozone, acetonitrile, and $\mathrm{NO}_{\mathrm{x}}$ for the whole study with the period used for the chemical mass balance model indicated. Figure 2 shows the time series of $\mathrm{CO}$, benzene toluene, formaldehyde, acetaldehyde black carbon, and organic $\mathrm{PM}_{1}$. A typical diel pattern was observed: elevated concentrations in the mornings, decreasing into the afternoon as the boundary layer expanded, and increasing again in the late afternoon to early evening as a surface inversion layer forms. On 15 and 16 January wind speeds were very low, producing a stagnation event and the highest pollutant concentrations for the study period. Starting midmorning on 16 January clear skies gave way to an extended overcast period of persistent stratus cloud cover that produced very low and much more constant primary pollutant concentrations. The chemical mass balance model was run to perform source attribution for $\mathrm{CO}$, formaldehyde, acetaldehyde, benzene, toluene, $\mathrm{C}_{2}$-alkylbenzenes, black carbon, and organic $\mathrm{PM}_{1}$.

\subsection{Results of the Chemical Mass Balance Model}

The MLR model produced results that closely followed observations for primary pollutants, implying that residential wood combustion and mobile sources were the dominant emission sources impacting the site. For $\mathrm{CO}$, benzene, toluene, $\mathrm{C}_{2}$-alkylbenzenes, and black carbon, pollutants which are thought to be mostly primary emissions from wood smoke and mobile sources, the slope and $r^{2}$ values for the modeled to measured correlations were between 0.81 and 0.93 as shown in Figure 3 and Table 1 (factors from the log-transformed data are shown for reference in Table S3). Table 1 also shows the regression coefficients (emission ratios). The high $r^{2}$ values indicate that the chemical mass balance model did a good job of capturing the trend as well as the overall magnitude of these primary pollutant concentrations. Interestingly, for the pollutants that could potentially have secondary sources from atmospheric chemical processing (formaldehyde, acetaldehyde, and organic $\mathrm{PM}_{1}$ ), the measured to modeled comparisons yielded poorer correlations with slope and $r^{2}$ values of 0.74 to 0.80 . Poorer correlations along with the large intercepts $\left(C_{0}\right)$ of the formaldehyde and organic $\mathrm{PM}_{1}$ correlations suggest that additional sources or processes contributed to the abundances of these pollutants. For these compounds the model reproduced morning and evening abundances reasonably well but underpredicted the afternoon abundance. Additional figures showing temporal dependence of the source attribution and model residuals are given in the supporting information. 


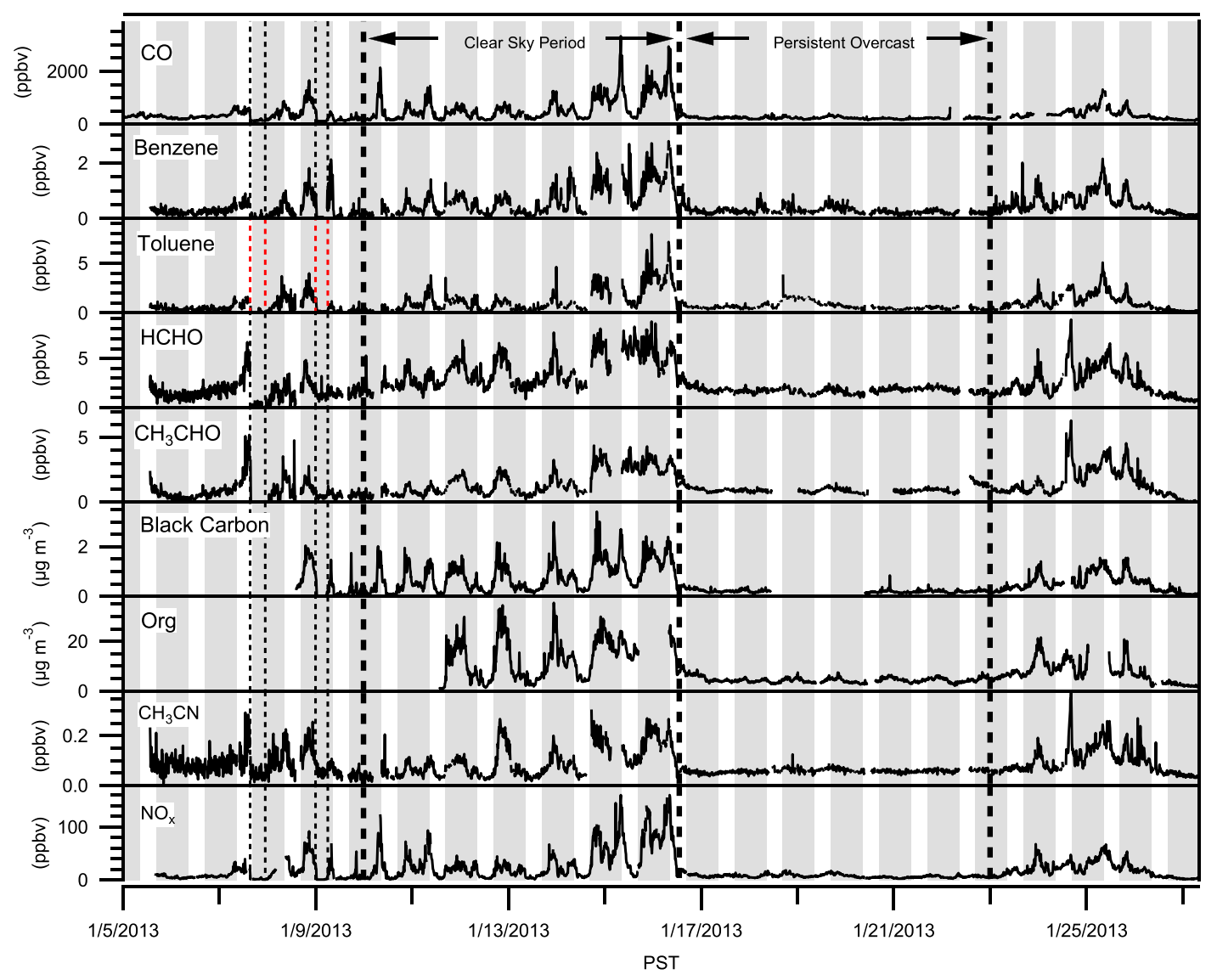

Figure 2. Time series of PTR-MS measurements of $\mathrm{CO}$, benzene, toluene, formaldehyde, acetaldehyde, black carbon, organic $\mathrm{PM}_{1}$, acetonitrile, and $\mathrm{NO}_{\mathrm{x}}$ for the entire campaign. The areas denoted by dashed lines on 07 and 09 January indicate the high-wind period, during which regional backgrounds were determined for $\mathrm{CO}$ and $\mathrm{CH}_{3} \mathrm{CN}$. Shaded areas indicate nighttime and unshaded areas indicate daytime.

The higher abundances of $\mathrm{HCHO}, \mathrm{CH}_{3} \mathrm{CHO}, \mathrm{NO}_{3}{ }^{-} \mathrm{PM}_{1}$, and organic $\mathrm{PM}_{1}$ than predicted by the primary source tracers in the afternoon suggest secondary sources, somewhat surprising for this wintertime environment. The afternoon deviations were apparent for two afternoons during the strong stagnation period, as illustrated in Figure 4, which shows time series of $\mathrm{HCHO}$, organic $\mathrm{PM}_{1}$, and $\mathrm{NO}_{3}{ }^{-} \mathrm{PM}_{1}$ for 14 and 15 January. The simultaneous increase of surface air temperature, odd oxygen $\left(\mathrm{O}_{3}+\mathrm{NO}_{2}\right)$, and $\mathrm{NO}_{3}{ }^{-} \mathrm{PM}_{1}$ soon after sunrise on 15 January suggests mixing phenomena, whereby elevated concentrations were being mixed down to the surface from the residual layer above. Formaldehyde and organic $\mathrm{PM}_{1}$ were also elevated during that day but did not display the same temporal increase at sunrise as $\mathrm{NO}_{3}{ }^{-} \mathrm{PM}_{1}$, perhaps a result of similar abundances between the residual layer and nighttime surface layer concentrations for these compounds. We hypothesize that residual layer $\mathrm{NO}_{3}$ radical chemistry produces $\mathrm{HCHO}, \mathrm{NO}_{3}{ }^{-} \mathrm{PM}_{1}$, and organic $\mathrm{PM}_{1}$ at night, and mixing of these secondary products to the surface as the boundary layer expands may explain the elevated daytime concentrations not captured by the MLR model.

From the regression coefficients the MLR model results indicate that residential wood combustion is responsible for the majority of formaldehyde (73\%), acetaldehyde (69\%), black carbon (55\%), and organic $\mathrm{PM}_{1}$ (100\%) abundance, while mobile sources are responsible for most of the CO (83\%), benzene (64\%), toluene $(81 \%)$, and $\mathrm{C}_{2}$-alkylbenzenes (81\%). The percentages were calculated as the fractional contribution of wood smoke and mobile sources to the average concentration of the species above the model offset value $C_{o}$. The $C_{o}$ value was similar to the afternoon values of the measured primary pollutants and represents a mixed source component with local contributions from roadway emissions and wood smoke combustion plus advective mass inflow contributions from outside the air shed. Given the low abundances in the afternoon, the PTR-MS measurement precision was not sufficient for the MLR model to separate the afternoon local 

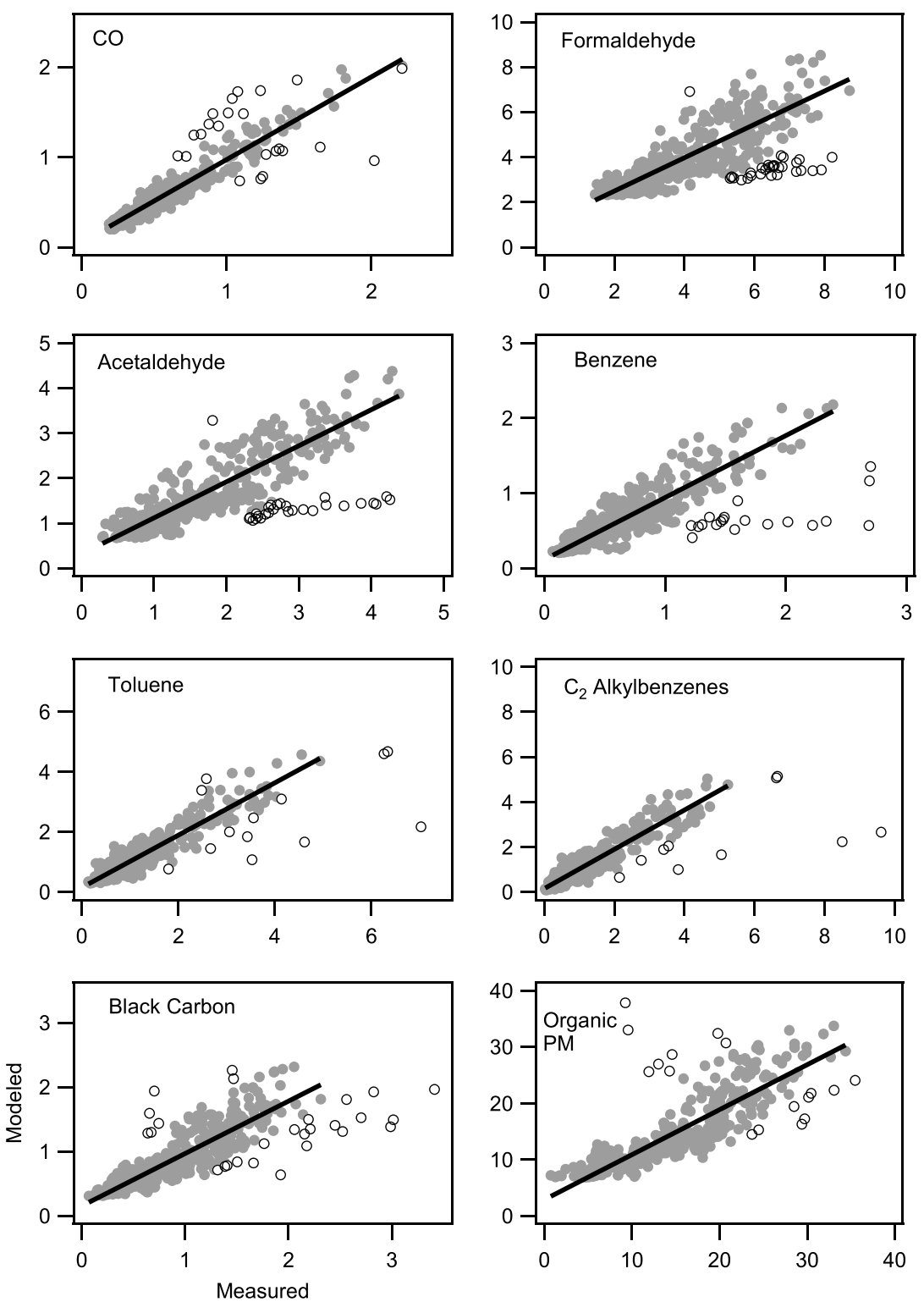

Figure 3. Correlations of MLR reproduced pollutant concentrations ( $y$ axis) to measured pollutant concentrations ( $x$ axis). Units are ppmv for CO; ppbv for formaldehyde, acetaldehyde, benzene, toluene, and $\mathrm{C}_{2}$-alkylbenzenes; and $\mu \mathrm{g} \mathrm{m}^{-3}$ for black carbon and organic PM. Open circles indicate the outliers that were identified in the MLR analysis and not included in the regression fit.

Table 1. MLR Model Output Factors and $r^{2}$ for MLR-Modeled Versus MLR-Measured Correlations Shown in Figure $3 a^{a}$

Compound

$\mathrm{CO}$

$\mathrm{HCHO}$

$\mathrm{CH}_{3} \mathrm{CHO}$

Benzene

Toluene

$\mathrm{C}_{2}$-alkylbenzenes

Black carbon $\left(\mathrm{g} / \mathrm{g}, \mathrm{mg} / \mathrm{g}, \mu \mathrm{g} \mathrm{m}^{-3}\right)$

Organic $\mathrm{PM}_{1}\left(\mathrm{~g} / \mathrm{g}, \mathrm{mg} / \mathrm{g}, \mu \mathrm{g} \mathrm{m}{ }^{-3}\right)$
Wood Smoke Emission Ratio $\left(\mathrm{mol} / \mathrm{mol} \mathrm{CH}_{3} \mathrm{CN}\right.$ )

Mobile Emission Ratio $\left(\mathrm{mmol} / \mathrm{mol} \mathrm{NO}_{x}\right)$

$12,100 \pm 960$

$14.4 \pm 5.5$

$9.9 \pm 4.5$

$10.4 \pm 1.6$

$28.5 \pm 2.6$

$33.3 \pm 3.1$

$5.0 \pm 1.3$

$0.0 \pm 14.0$

$\begin{array}{cc}C_{o} \text { (ppbv) } & r^{2} \\ 161.82 \pm 12.63 & 0.93 \\ 2.25 \pm 0.13 & 0.74 \\ 0.63 \pm 0.08 & 0.80 \\ 0.17 \pm 0.02 & 0.82 \\ 0.2 \pm 0.04 & 0.87 \\ -0.01 \pm 0.05 & 0.87 \\ 0.28 \pm 0.04 & 0.81 \\ 6.87 \pm 0.57 & 0.80\end{array}$

${ }^{\mathrm{a}}$ Units for black carbon and organic $\mathrm{PM}_{1}$ are $\mathrm{g} / \mathrm{g}$ for the wood smoke emission ratio, $\mathrm{mg} / \mathrm{g}$ for the mobile source emission ratio, and $\mu \mathrm{g} \mathrm{m}{ }^{-3}$ for $C_{0}$. 


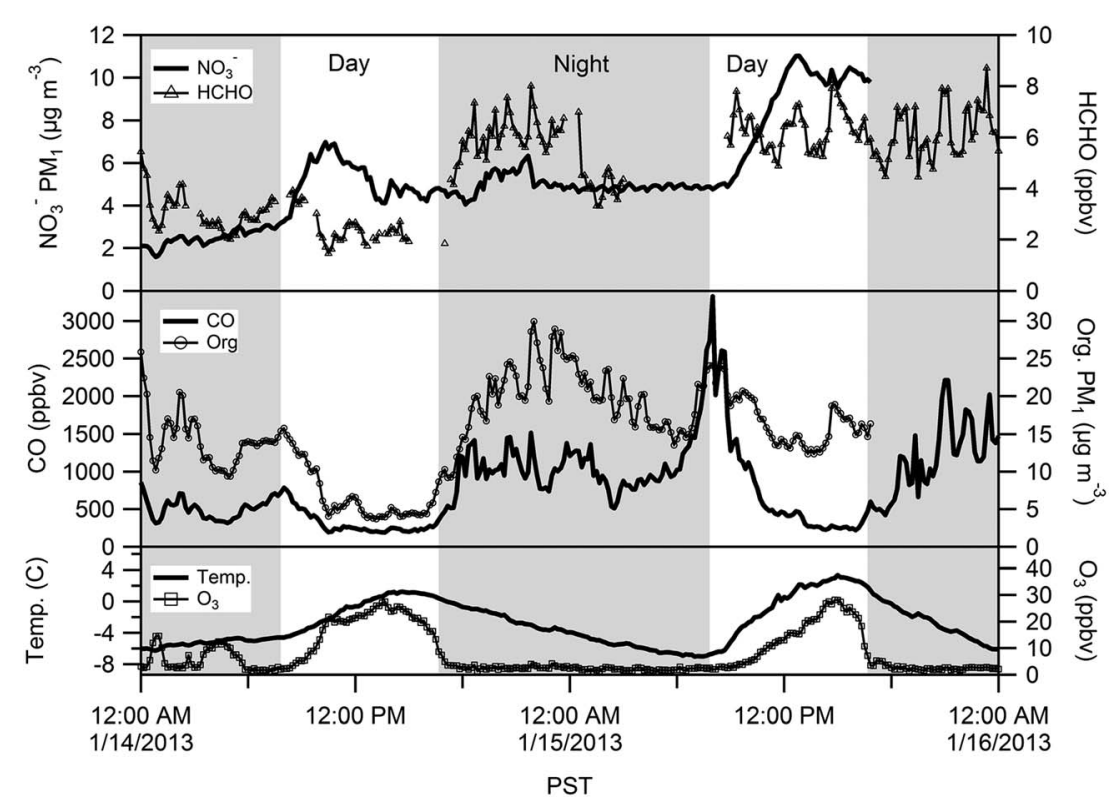

Figure 4. Time series of $\mathrm{O}_{3}, \mathrm{CO}$, formaldehyde, organic $\mathrm{PM}_{1}, \mathrm{NO}_{3}{ }^{-} \mathrm{PM}_{1}$, and temperature for a clear-sky stagnation event. The onset of the increase in surface air temperature soon after sunrise is coincident with an increase in $\mathrm{NO}_{3}{ }^{-}$and odd oxygen $\left(\mathrm{O}_{3}+\mathrm{NO}_{2}\right)$, suggesting elevated levels in the residual layer mixing to the surface. Compounds with large primary emission sources, such as $\mathrm{CO}$, typically have lower mixing ratios in the afternoon compared to the evening. The afternoon of the strong stagnation period of 15 January was an exception with high levels of $\mathrm{HCHO}$ and organic PM.

source contributions in the air shed from the "regional background" contribution. For some compounds, the model offsets $\left(C_{o}\right)$ were substantial compared to the average modeled concentration, notably formaldehyde $(58 \%)$, organic $\mathrm{PM}_{1}(47 \%)$, and acetaldehyde $(40 \%)$. High-offset values were due to high afternoon abundances that may be attributed to secondary sources. Thus, the two-variable primary pollutant source model was not able to explain all the temporal variation observed for these pollutants. The $100 \%$ attribution of organic $\mathrm{PM}_{1}$ obviously reflects limitations in the method for performing source attribution of organic $\mathrm{PM}_{1}$ since mobile sources are known to emit organic $\mathrm{PM}_{1}$. The MLR model is thus likely overestimating the residential wood combustion source because it is larger than the mobile source and thus drives primary organic $\mathrm{PM}_{1}$ variability. Table 2 summarizes the percentage attributed to each source with associated uncertainty. The uncertainties are the standard deviation of the average percentages calculated from 100 realizations of the regression using block bootstrapping as described above.

These attribution results from MLR model were compared to the 2011 winter emission inventory using the ratio of residential wood combustion percentage contribution to the mobile source contribution. This ratio for both the 2011 winter emission inventory and the MLR model is shown in Table 3. The emission inventory indicates that $\mathrm{CO}$ and VOC emissions were dominated by mobile sources, with residential wood combustion to mobile source ratios of 0.11 and 0.26 , respectively, and that $\mathrm{PM}_{2.5}$ was dominated by residential wood combustion, with a ratio of 3.23. The MLR model results generally mirror these conclusions for CO, benzene,

Table 2. Average Percentage of Pollutants Attributed to Wood Smoke and Mobile Sources by the Two-Variable MLR Model

Compound

Wood Smoke Percent Contribution Mobile Source Percent Contribution

\begin{tabular}{lcc}
\hline $\mathrm{CO}$ & $17 \pm 6$ & $83 \pm 4$ \\
$\mathrm{HCHO}$ & $73 \pm 9$ & $27 \pm 8$ \\
$\mathrm{CH}_{3} \mathrm{CHO}$ & $69 \pm 14$ & $31 \pm 6$ \\
Benzene & $36 \pm 9$ & $64 \pm 4$ \\
Toluene & $19 \pm 7$ & $81 \pm 4$ \\
$\mathrm{C}_{2}$-alkylbenzenes & $19 \pm 7$ & $81 \pm 5$ \\
Black carbon & $55 \pm 10$ & $45 \pm 6$ \\
Organic $\mathrm{PM}_{1}$ & $100 \pm 8$ & $0 \pm 7$ \\
\hline
\end{tabular}


Table 3. Comparison of the Ratio of Wood Smoke Contribution to Mobile Source Contribution Between the 2011 Winter Emission Inventory and the MLR Model Results ${ }^{a}$

2011 Winter Emission Inventory

\begin{tabular}{|c|c|c|c|}
\hline Compound & $\begin{array}{l}\text { Wood Smoke/Mobile } \\
\text { Source Contribution }\end{array}$ & Compound & $\begin{array}{l}\text { Wood Smoke/Mobile } \\
\text { Source Contribution }\end{array}$ \\
\hline $\mathrm{CO}$ & 0.11 & $\mathrm{CO}$ & 0.21 \\
\hline \multirow[t]{5}{*}{ VOCs } & 0.26 & $\mathrm{HCHO}$ & 2.7 \\
\hline & & $\mathrm{CH}_{3} \mathrm{CHO}$ & 2.2 \\
\hline & & Benzene & 0.56 \\
\hline & & Toluene & 0.23 \\
\hline & & $\mathrm{C}_{2}$-alkylbenzenes & 0.24 \\
\hline \multirow[t]{2}{*}{$\mathrm{PM}_{2.5}$} & 3.2 & Black carbon & 1.2 \\
\hline & & $\mathrm{OPM}_{1}$ & $\infty$ \\
\hline
\end{tabular}

${ }^{\mathrm{a}}$ The ratios for the 2011 winter emission inventory were molar ratios for $\mathrm{CO}$ and VOCs and mass ratios for PM 2.5 . The ratios from the MLR model were on a molar basis for $\mathrm{CO}, \mathrm{HCHO}, \mathrm{CH}_{3} \mathrm{CHO}$, benzene, toluene, and $\mathrm{C}_{2}$-alkylbenzenes and on a mass basis for black carbon and organic $\mathrm{PM}_{1}$.

toluene, $\mathrm{C}_{2}$-alkylbenzenes, and organic $\mathrm{PM}_{1}$. The ratio for $\mathrm{CO}$ suggests that the emission inventory may be underestimating the influence of residential wood combustion by about a factor of 2 . Because speciation of VOCs in the emission inventory is sparse, it is difficult to directly compare the wood combustion to mobile source contribution ratio for individual VOCs to the emission inventory. Interestingly, the MLR model results suggest that emissions of the air toxics formaldehyde and acetaldehyde are dominated by residential wood combustion. Aldehydes are known to make up a large portion of the gas phase emissions from residential wood combustion [Schauer et al., 2001]. Benzene, toluene, and $C_{2}$-alkylbenzenes were dominated by mobile source emissions.

The $\mathrm{PM}_{2.5}$ emission inventory is not speciated, making it difficult to compare the source contribution ratio directly with organic $\mathrm{PM}_{1}$ and black carbon. The inventory states that residential wood combustion emissions of $\mathrm{PM}_{2.5}$ are a factor of 3.2 greater than mobile emissions. The MLR model results were consistent with this; the MLR model found the mobile source contribution to organic $\mathrm{PM}_{1}$ to be negligible compared to wood burning. The black carbon source contribution ratio in the MLR model was evenly split between residential wood burning and mobile sources. This suggests that, in contrast to organic $\mathrm{PM}_{1}$, black carbon had a substantial contribution from mobile sources at our study site. This is not necessarily at odds with the emission inventory since black carbon made up a relatively small fraction $(\sim 2 \%)$ of the overall $\mathrm{PM}_{2.5}$ mass during the model period.

\subsection{Comparison of Mobile Source Emission Factors to MOVES}

MOVES model results for Yakima County, WA, in the winter season were obtained from WSDOE and compared to results from the chemical mass balance model in Table 4. The MOVES model emissions were reported as a mass per season. For each species of interest in this study, molar emission ratios were calculated using the molecular weight of each compound and reported in units of $\mathrm{mmol} / \mathrm{mol} \mathrm{NO}_{\mathrm{x}}$. $\mathrm{NO}_{\mathrm{x}}$ emissions are reported in MOVES as grams of $\mathrm{NO}_{2}$, so a molecular weight of 46 was used to convert $\mathrm{NO}_{x}$ mass emission rates into molar emission rates. The black carbon emission ratio was left in mass units (mg/g NO$)_{x}$. $M L R$ emission ratios for benzene and toluene agree well with MOVES, matching almost exactly (within 7\%). The

Table 4. Comparison of Mobile Source Emission Ratios to $\mathrm{NO}_{\mathrm{x}}$ of the MLR Model Results to MOVES Model Output for Winter Season ${ }^{\mathrm{a}}$

Compound MOVES Emission Ratio to $\mathrm{NO}_{x}(\mathrm{mmol} / \mathrm{mol})$ MLR Model Emission Ratios to $\mathrm{NO}_{x}(\mathrm{mmol} / \mathrm{mol})$

MLR/MOVES

\begin{tabular}{lccc}
\hline CO & 16,114 & $12,099 \pm 956$ & $14.4 \pm 5.6$ \\
Formaldehyde & 11.4 & $9.9 \pm 4.5$ & 1.33 \\
Acetaldehyde & 8.21 & $10.4 \pm 1.6$ & 0.79 \\
Benzene & 11.1 & $28.5 \pm 2.6$ & 0.83 \\
Toluene & 29.5 & $33.3 \pm 3.1$ & 1.07 \\
C $_{2}$-alkylbenzenes & 23.0 & $5.0 \pm 1.3$ & 1.04 \\
Black carbon (mg/g) & 16.1 & 0.69 & \\
\hline
\end{tabular}

${ }^{\mathrm{a}}$ Gas phase pollutant emission ratios are in units of $\mathrm{mmol} / \mathrm{mol} \mathrm{NO}_{\mathrm{x}}$, and the black carbon emission ratio is in units of $\mathrm{mg} / \mathrm{g} \mathrm{NO}_{\mathrm{x}}$. 
formaldehyde and acetaldehyde emission ratios were higher in the MLR model than in moves by $21 \%$ and $26 \%$, respectively. However, the MOVES emission ratios are within 1 standard deviation of the MLR emission ratios, meaning that the MLR model did not return results significantly different from MOVES. The $\mathrm{C}_{2}$-alkylbenzene emission ratio is estimated about $45 \%$ higher by the MLR model than by MOVES. Solvent emissions could have some impact on artificially enhancing this emission ratio, as xylenes are a chemical species listed in the emission inventory documentation for solvents [WSDOE, 2013]. Therefore, it is difficult to say definitively that there are issues with MOVES model estimates of $C_{2}$-alkylbenzene emissions.

The major discrepancies between emission ratios from MOVES and the MLR model occur in the CO and black carbon data. For CO, MOVES predicts an emission ratio that is about 33\% greater than what the MLR model returned. One possible reason for this discrepancy is emissions from off-road vehicles and rail traffic, which are large emitters of $\mathrm{NO}_{x}$ relative to $\mathrm{CO}$. Off-road vehicles, which are mostly heavy-duty diesel engines, are also known to emit significant amounts of black carbon, especially relative to gasoline vehicles [Schauer et al., 1999; Schauer et al., 2002]. It is important to note that the MOVES model was applied on the county level, while this study had a much smaller footprint. This means that black carbon emissions in the urban neighborhood where our study took place may not be representative of on-road black carbon emissions from Yakima County on the whole. While our results suggest that MOVES is overpredicting wintertime on-road black carbon emissions, measurements would need to be performed in more locations to confirm this.

\subsection{Wood Smoke Emission Factors}

While there are many measurements of emission factors developed for wood stove emissions of PM, CO, and VOCs, very few include measurements of acetonitrile. However, one study, by Grieshop et al. [2009], made measurements of fresh emissions from a wood stove and reported benzene/CO, toluene/CO, and acetonitrile/CO ratios. The ranges of emission ratios tabulated reflect the range across all wood types used and all burning conditions tested. This included laurel oak and yellow pine wood types and flaming with embers, smoldering and flaming, and smoldering and dying flame-burning conditions [Grieshop et al., 2009]. The $\mathrm{CO}$ emission ratio from the MLR model was $1135 \pm 322 \mathrm{~mol} / \mathrm{mol} \mathrm{CH}_{3} \mathrm{CN}$, which was just below the low end of the range of emission ratios calculated from Grieshop et al. [2009], which spanned $1250-10,000 \mathrm{~mol} / \mathrm{mol} \mathrm{CH}_{3} \mathrm{CN}$. The observed benzene emission ratio of $2.8 \pm 0.8 \mathrm{~mol} / \mathrm{mol} \mathrm{CH}_{3} \mathrm{CN}$ fits in the low end of the range seen by Grieshop et al. [2009], which was $1.0-8.0 \mathrm{~mol} / \mathrm{mol} \mathrm{CH}_{3} \mathrm{CN}$. The observed toluene emission ratio of $3.2 \pm 1.1 \mathrm{~mol} / \mathrm{mol} \mathrm{CH}_{3} \mathrm{CN}$, however, was about $28 \%$ higher than the top end of the range from Grieshop et al. [2009], which was $0.0-2.5 \mathrm{~mol} / \mathrm{mol} \mathrm{CH}_{3} \mathrm{CN}$. Because the MLR model agreed well with observations for $\mathrm{CO}$ and toluene $\left(r^{2}=0.93\right.$ for $\mathrm{CO}$ and $r^{2}=0.87$ for toluene), this disagreement suggests that wood-burning emissions in Yakima, WA, are somewhat different than the emission profiles reported by Grieshop et al. [2009]. This could be due to a variety of factors including stove types, fuel type and fuel seasoning, and burning conditions.

Comparisons were also performed to field observations of organics to acetonitrile [Sarkar et al., 2016] and emission ratios from burning of ponderosa pine [Stockwell et al., 2015] in more recent works. Sarkar et al. [2016] presents a field study in the Kathmandu Valley in Nepal during wintertime, which was thought to be heavily influenced by biomass-burning emissions. From their observations of the acetonitrile, benzene, and toluene concentrations \pm 1 standard deviation over the course of their study, ranges of the enhancement ratios of benzene and toluene relative to acetonitrile were calculated. The range for the benzene to acetonitrile enhancement ratio was $1.1-5.5 \mathrm{~mol} / \mathrm{mol} \mathrm{CH}_{3} \mathrm{CN}$, and the range for the toluene to acetonitrile enhancement ratio was $0.8-2.7 \mathrm{~mol} / \mathrm{mol} \mathrm{CH} \mathrm{CHN}_{3}$. The MLR emission ratio for benzene (2.8) was right in the middle of this range, and the emission ratio for toluene (3.2) was about $17 \%$ higher than the top of this range. Stockwell et al. [2015] performed a detailed set of emission measurements of biomass-burning emissions from different sources. For our study we have chosen to compare their emission ratios for ponderosa pine to the MLR emission ratios, since ponderosa pine is prevalent in the Pacific Northwest and was likely burned in Yakima during our study. Stockwell et al. [2015] reported emission ratios of 406-1029 mol CO per mol $\mathrm{CH}_{3} \mathrm{CN}, 2.2-4.7 \mathrm{~mol}$ benzene to $\mathrm{mol} \mathrm{CH} \mathrm{CH}_{3} \mathrm{CN}$, and 4.2-9.5 mol toluene to mol $\mathrm{CH}_{3} \mathrm{CN}$. The MLR emission ratio for benzene was within the range reported by Stockwell et al. [2015], while the emission ratio for CO was about $10 \%$ above the range and the emission ratio for toluene was about $23 \%$ below the range. In general, MLR emission ratios to $\mathrm{CH}_{3} \mathrm{CN}$ agreed fairly well with observations from these two more recent papers. Relatively small differences 
can likely be explained by difference in fuel types, burning conditions, and types of biomass-burning sources in the case of Sarkar et al. [2016].

\section{Conclusions}

A suite of air pollutants were measured in Yakima, WA, during January 2013 as part of a wintertime air quality study to identify sources of particulate matter. A multiple linear regression (MLR) model was applied to $10 \mathrm{~min}$ average data for a 5 day period with large temporal variations in pollutant concentrations. The MLR model attributed pollutant abundance to either residential wood combustion or mobile sources which are the dominant emission sources in the city. Acetonitrile was used as a tracer of residential wood smoke emissions and $\mathrm{NO}_{\mathrm{x}}$ as a tracer of fossil fuel combustion (dominated by vehicle emissions). Results from the MLR model showed that mobile sources were the largest contributors of CO (83\%), benzene (64\%), toluene (81\%), and $\mathrm{C}_{2}$-alkylbenzenes (81\%), while residential wood combustion was the largest emitter of formaldehyde (73\%), acetaldehyde (69\%), black carbon (55\%), and organic $\mathrm{PM}_{1}(100 \%)$. While attribution of all of the organic $\mathrm{PM}_{1}$ to wood smoke is likely an overestimate, our results suggest that residential wood combustion is not only a major source of PM as expected but also a major source of the air toxics formaldehyde, acetaldehyde, and benzene. Reducing residential wood combustion emissions would thus have a significant multipollutant benefit to air quality. Interestingly, there was a significant component of formaldehyde, acetaldehyde, and organic $\mathrm{PM}_{1}$ that appeared to be secondary in origin, associated with 2 days during a stagnation event where these compounds were elevated during the morning and afternoon. These elevated periods might be caused by down mixing from the residual layer, implying a nighttime residual layer chemistry source. When comparing MLR model mobile source emission ratios to MOVES 2010b model county-level output we found that the emission ratios to $\mathrm{NO}_{x}$ agreed very well for benzene and toluene. The emission ratios also agreed within 1 standard deviation for formaldehyde and acetaldehyde. The main differences between MLR results and MOVES model output were in the $\mathrm{CO} / \mathrm{NO}_{x}$ emission ratio, which was a factor of 1.33 higher in the MOVES model output and the black carbon/NO $\mathrm{NO}_{\mathrm{x}}$ emission ratio, which was a factor of 3 higher in the MOVES model output.

Acknowledgments

This research was supported by the National Science Foundation AGS program grant 1140176 and by a grant from the Washington State Department of Ecology. We would like to acknowledge the support and cooperation of Yakima Valley Community College for hosting the study site. We thank Sally Otterson from WSDOE for providing the MOVES model output and seasonal 2011 NEI data. Data from the YAWNS study are available upon request to the corresponding author (e-mail: tjobson@wsu.edu).

\section{References}

Alfarra, M. R., A. Prévôt, S. Szidat, J. Sandradewi, S. Weimar, V. Lanz, D. Schreiber, M. Mohr, and U. Baltensperger (2007), Identification of the mass spectral signature of organic aerosols from wood burning emissions, Environ. Sci. Technol., 41(16), 5770-5777.

Chen, J., J. Vaughan, J. Avise, S. O'Neill, and B. Lamb (2008), Enhancement and evaluation of the AIRPACT of the ozone and PM2.5 forecast system for the Pacific Northwest, J. Geophys. Res., 113, D14305, doi:10.1029/2007JD0095544.

de Foy, B., and J. J. Schauer (2015), Origin of high particle number concentrations reaching the St. Louis, Midwest Supersite, J. Environ. Sci., 34 , 219-231.

de Gouw, J. A., C. Warneke, D. D. Parrish, J. S. Holloway, M. Trainer, and F. C. Fehsenfeld (2003), Emission sources and ocean uptake of acetonitrile $\left(\mathrm{CH}_{3} \mathrm{CN}\right)$ in the atmosphere, J. Geophys. Res., 108(D11), 4329, doi:10.1029/2002JD002897.

de Gouw, J. D., and C. Warneke (2007), Measurements of volatile organic compounds in Earth's atmosphere using proton transfer reaction mass spectrometry, Mass Spectrom. Rev., 223-257.

Decarlo, P. F., et al. (2006), Aerosol mass spectrometer, Anal. Chem., 78(24), 8281-8289.

EPA (2010), Technical guidance on the use of MOVES2010 for emission inventory preparation in state implementation plans and transportation conformity Report: EPA-420-B-10-023.

Erickson, M. H., M. Gueneron, and B. T. Jobson (2014), Measuring long chain alkane sin diesel engine exhaust by thermal desorption PTR-MS, Atmos. Meas. Tech., 7, 225-239.

Friedlander, S. K. (1973), Chemical element balances and identification of air pollution sources, Environ. Sci. Technol., 7(3), $238-245$.

Fujita, E. M., J. G. Watson, J. C. Chow, and Z. Lu (1994), Validation of the chemical mass balance receptor model applied to hydrocarbon source apportionment in the Southern California Air Quality Study, Environ. Sci. Technol., 28(9), 1633-1649.

Grieshop, A. P., J. M. Logue, N. M. Donahue, and A. L. Robinson (2009), Laboratory investigation of photochemical oxidation of organic aerosol from wood fires 1: Measurement and simulation of organic aerosol evolution, Atmos. Chem. Phys., 9, $1263-1277$.

Holzinger, R., A. Jordan, A. Hansel, and W. Lindinger (2001), Automobile emissions of acetonitrile: Assessment of its contribution to the global source, J. Atmos. Chem., 38(2), 187-193.

Holzinger, R., J. Williams, G. Salisbury, T. Klüpfel, M. de Reus, M. Traub, P. J. Crutzen, and J. Lelieveld (2005), Oxygenated compounds in aged biomass burning plumes over the eastern Mediterranean: Evidence for strong secondary production of methanol and acetone, Atmos. Chem. Phys., 5(1), 39-46.

Jobson, B. T., and J. K. McCoskey (2010), Sample drying to improve HCHO measurements by PTR-MS instruments: laboratory and field measurements, Atmos. Chem. Phys., 10, 1821-1835.

Jost, C., J. Trentmann, D. Sprung, M. O. Andreae, J. B. McQuiad, and H. Barjet (2003), Trace gas chemistry in a young biomass burning plume over Namibia: Observations and model simulations, J. Geophys. Res., 108(D13), 18-1-18-13, doi:10.1029/2002JD002431.

Karl, T. G., T. J. Christian, R. J. Yokelson, P. Artaxo, W. M. Hao, and A. Guenther (2007), The tropical forest and fire emissions experiment: Method evaluation of volatile organic compound emissions measured by PTR-MS, FTIR, and GC from tropical biomass burning, Atmos. Chem. Phys., 7(3), 8755-8793.

Karl, T., A. Hansel, T. Mark, W. Lindinger, and D. Hoffmann (2002), Trace gas monitoring at the Mauna Loa baseline observatory using proton-transfer reaction mass spectrometry, Int. J. Mass Spectrom., 6, 1-12.

Laborde, M., et al. (2012), Single Particle Soot Photometer intercomparison at the AIDA chamber, Atmos. Meas. Tech., 5(12), $3077-3097$. 
Lack, D. A., et al. (2013), Brown carbon absorption linked to organic mass tracers in biomass burning particles, Atmos. Chem. Phys., 13(5), $2415-2422$.

Lanz, V. A., et al. (2008), Source attribution of submicron organic aerosols during wintertime inversions by advanced factor analysis of aerosol mass spectra, Environ. Sci. Technol., 42(1), 214-220.

Lindinger, W., A. Hansel, and A. Jordan (1998), On-Line monitoring of volatile organic compounds at pptv levels by means of proton-transferreaction mass spectrometry (PTR-MS) medical applications, food control and environmental research, Int. J. Mass Spectrom. Ion Processes, 173(3), 191-241.

Maykut, N. N., J. Lewtas, E. Kim, and T. V. Larson (2003), Source apportionment of $\mathrm{PM}_{2.5}$ at an urban IMPROVE site in Seattle, Washington, Environ. Sci. Technol., 37(22), 5135-5142.

Sarkar, C., V. Sinha, V. Kumar, M. Rupakheti, A. Panday, K. S. Mahata, D. Rupakheti, B. Kathayat, and M. G. Lawrence (2016), Overview of VOC emissions and chemistry from PTR-TOF-MS measurements during the SusKat-ABC campaign: High acetaldehyde, isoprene and isocyanic acid in wintertime air of the Kathmandu Valley, Atmos. Chem. Phys., 16(6), 3979-4003.

Schauer, J. J., M. J. Kleeman, G. R. Cass, and B. R. Simoneit (1999), Measurement of emissions from air pollution sources. 2. $C_{1}$ through $C_{30}$ organic compounds from medium duty diesel trucks, Environ. Sci. Technol., 33(10), 1578-1587.

Schauer, J. J., M. J. Kleeman, G. R. Cass, and B. R. Simoneit (2001), Measurement of emissions from air pollution sources. 3 . $C_{1}-C_{29}$ organic compounds from fireplace combustion of wood, Environ. Sci. Technol., 35(9), 1716-1728.

Schauer, J. J., M. J. Kleeman, G. R. Cass, and B. R. T. Simoneit (2002), Measurement of emissions from air pollution sources. $5 . C_{1}-C_{32}$ organic compounds from gasoline-powered motor vehicles, Environ. Sci. Technol., 36(6), 1169-1180.

Schwarz, J. P., et al. (2006), Single-particle measurements of midlatitude black carbon and light-scattering aerosols from the boundary layer to the lower stratosphere, J. Geophys. Res., 111, D16207, doi:10.1029/2006JD007076.

Snider, J. R., and G. A. Dawson (1984), Surface acetonitrile near Tucson, Arizona, Geophys. Res. Lett., 11(3), 241-242, doi:10.1029/ GL011i003p00241.

Stockwell, C. E., P. R. Veres, J. Williams, and R. J. Yokelson (2015), Characterization of biomass burning emissions from cooking fires, peat, crop residue, and other fuels with high-resolution proton-transfer-reaction time-of-flight mass spectrometry, Atmos. Chem. Phys., 15(2), $845-865$.

Tian, Y. Q., J. D. Radke, P. Gong, and Q. Yu (2004), Model development for spatial variation of $\mathrm{PM}_{2.5}$ emissions from residential wood burning, Atmos. Environ., 38(6), 833-843.

VanReken, T., T. Jobson, B. Lamb, H. Liu, and S. Kaspari (2014), The Yakima Air Wintertime Nitrate Study (YAWNS) final report, Washington State Department of Ecology. [Available at http://www.ecy.wa.gov/programs/air/air_monitoring_data/PDFs/ Yakima_Air_Winter_Study_Report.pdf.]

Vaughan, J., et al. (2004), A numerical daily air quality forecast system for the Pacific Northwest, Bull. Am. Meteorol. Soc., 85(4), 549-560.

Ward, T., and T. Lange (2010), The impact of wood smoke on ambient $\mathrm{PM}_{2.5}$ in northern Rocky Mountain Valley communities, Environ. Pollut., 158(3), 723-729.

Ward, T. J., L. R. Rinehart, and T. Lange (2006), The 2003/2004 Libby, Montana PM 2.5 source apportionment research study, Aerosol Sci. Technol., 40(3), 166-177.

Watson, J. G. (1984), Overview of receptor model principles, J. Air Pollut. Control Assoc., 34(6), 619-623.

Watson, J. G., N. F. Robinson, and J. C. Chow (1990), The USEPA/DRI Chemical Mass Balance Receptor Model, CMB 7.0, Environ. Software, 5(1), 38-49.

WSDOE (2013), Washington State 2011 County Emissions Inventory, Washington State Department of Ecology. [Available at http://www.ecy. wa.gov/programs/air/emissioninventory/PDFs/WA_2011_County_El_Upd10.2014.pdf.]

Yokelson, R. J., et al. (2009), Emissions from biomass burning in the Yucatan, Atmos. Chem. Phys., 9, 5785-5812.

Yuan, B., et al. (2010), Biomass burning contributions to ambient VOCs species at a receptor site in the Pearl River Delta (PRD), China, Environ. Sci. Technol., 44(12), 4577-4582. 